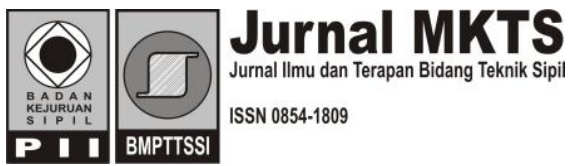

\title{
Perbandingan Hasil Pemodelan Aliran Satu Dimensi Unsteady Flow dan Steady Flow pada Banjir Kota
}

\author{
Andreas Tigor Oktaga \\ Balai Besar Wilayah Sungai Pemali - Juana \\ Jl. Brigjend Soediarto No 375 \\ E-mail: oktaga21@gmail.com \\ Suripin \\ Jurusan Teknik Sipil, Fakultas Teknik, Universitas Diponegoro \\ J1.Prof. Soedarto, SH, Tembalang, Semarang 50275 \\ E-mail: suripin_ar@gmail.com \\ Suseno Darsono \\ Jurusan Teknik Sipil, Fakultas Teknik, Universitas Diponegoro \\ Jl.Prof. Soedarto, SH, Tembalang, Semarang 50275 \\ E-mail:sdarsono@hotmail.com
}

\begin{abstract}
One dimensional flow is often used as a flood simulation for the planning capacity of the river. Flood is a type of unsteady non-uniform flow, that can be simulated using HEC-RAS. HEC-RAS software is often used for flood modeling with a one-dimensional flow method. Unsteady flow modeling results in HEC-RAS sometimes refer to error and warning due to unstable analysis program. The stability program among others influenced bend in the river flow, the steep slope of the river bottom, and changes in cross-section shape. Because the flood handling required maximum discharge and maximum flood water level, then a steady flow is often used as an alternative to simulate the flood flow. This study aimed to determine the advantages and disadvantages of modeling unsteady non-uniform and steady non-uniform flow. The research location in the Kanal Banjir Barat, in the Semarang City. Hydraulics modeling uses HEC-RAS 4.1 and for discharge the plan is obtained from the HEC-HMS 3.5. Results of the comparison modeling hydraulics the modeling of steady non-uniform flow has a tendency water level is higher and modeling of unsteady non-uniform flow takes longer to analyze. Results of the comparison the average flood water level maximun is less than $15 \%$ ( $\pm 0,3$ meters), that is 0.27 meters $(13.16 \%)$ for $Q_{50}, 0.25$ meters $(11.56 \%)$ for $Q_{100}$, dan 0.16 meters $(4.73 \%)$ for $Q_{200}$. So the modeling steady non-uniform flow can still be used as a companion version the modeling unsteady non-uniform flow.
\end{abstract}

Keywords: HEC-RAS, Comparation, Steady non-uniform flow, Unsteady non-uniform flow.

\begin{abstract}
Abstrak
Aliran satu dimensi sering digunakan sebagai simulasi banjir untuk perencanaan kapasitas sungai. Banjir merupakan jenis aliran unsteady non-uniform flow yang dapat disimulasikan menggunakan HEC-RAS. Hasil pemodelan unsteady non-uniform flow pada HEC-RAS tidak jarang terdapat keterangan error dan warning disebabkan analisis program tidak stabil. Tingkat kestabilan program antara lain dipengaruhi kelokan alur sungai, kemiringan dasar sungai yang curam, dan perubahan bentuk potongan melintang. Karena penanganan banjir yang dibutuhkan debit maksimal dan muka air banjir maksimal, maka aliran steady nonuniform flow sering dijadikan sebagai alternatif mensimulasikan aliran banjir. Penelitian ini bertujuan untuk mengetahui kelebihan dan kekurangan pemodelan unsteady non-uniform flow dan steady non-uniform flow. Lokasi penelitian di Kanal Banjir Barat yang terletak di Kota Semarang. Pemodelan hidraulika menggunakan HEC-RAS 4.1 dan untuk debit rencana diperoleh dari HEC-HMS 3.5. Hasil perbandingan
\end{abstract}


pemodelan hidraulika didapatkan steady non-uniform flow memiliki kecenderungan elevasi muka air lebih tinggi dan pemodelan unsteady non-uniform flow membutuhkan waktu lebih lama. Dari hasil perbandingan didapat selisih rata - rata elevasi muka air banjir kurang dari 15\% ( \pm 0,3 meter), yaitu 0,27 meter $(13,16 \%)$ untuk $Q_{50}, 0,25$ meter $(11,56 \%)$ untuk $Q_{100}$, dan 0,16 meter $(4,73 \%)$ untuk $Q_{200 .}$. Sehingga pemodelan steady non-uniform flow masih dapat digunakan sebagai versi pendamping pemodelan unsteady non-uniform flow.

Kata-kata Kunci: HEC-RAS, Perbandingan, Steady non-uniform flow, Unsteady non-uniform flow.

\section{Pendahuluan}

Saluran drainase/sungai direncanakan mampu menampung debit air yang melintas supaya tidak meluap kedaratan dan menyebabkan banjir. Untuk penanganan yang optimal diperlukan perencanaan dengan hasil mendekati kondisi nyata. Pendekatan menggunakan pemodelan software sering kali dilakukan untuk perencanaan simulasi banjir dengan metode unsteady non-uniform flow. Software yang umum digunakan adalah HECRAS, sebagai software open source.

Namun dalam pemodelan pada HEC-RAS, tidak jarang ditemui kesulitan untuk memperoleh hasil analisis yang sempurna tanpa adanya keterangan error dan warning pada report program. Keterangan error dan warning dalam pemodelan unsteady non-uniform flow pada HEC-RAS umumnya dikarenakan tidak stabilnya profil muka air akibat pengaruh kerapatan jarak antar potongan melintang, perubahan bentuk potongan melintang yang ekstrim, maupun kemiringan dasar saluran yang curam.

Ketika pemodelan unsteady flow pada HEC-RAS terjadi kendala, biasanya para engineer mengalihkan pemodelan aliran menggunakan metode steady flow. Penggunaan model unsteady flow dan steady flow pada HEC-RAS perlu diketahui perbedaan hasilnya, maka penelitan ini akan membandingkan hasil pemodelan unsteady flow dan steady flow pada HEC-RAS. Sehingga dapat diketahui komponen yang mempengaruhi kestabilan pemodelan unsteady flow dan berapa porsen selisih elevasi muka air banjir hasil pemodelan steady flow terhadap unsteady flow.

Menurut Istiarto (2014) untuk melakukan penelusuran banjir (flood routing) di sungai, perlu simulasi aliran tak permanen. Jika hanya ingin memperkirakan muka air banjir di sepanjang sungai, dapat dilakukan simulasi aliran permanen, dengan catatan bahwa muka air banjir yang hasil hitungan akan lebih tinggi daripada seharusnya (over estimate). Menurut Goodell, C (2010) apabila simulasi banjir yang dihasilkan dengan unsteady flow kurang stabil, maka simulasi dapat dialihkan ke steady flow. Saya setuju untuk memiliki versi pendamping karena unsteady flow dianggap kurang akurat dengan adanya bentuk error. Dari sudut pandang numerik, persamaan energi memiliki keuntungan karena dapat diselesaikan secara analitis untuk menghasilkan solusi yang tepat. Pada aliran unsteady flow harus diubah kebentuk diskrit (finite difference approximation) untuk memecahkannya, sehingga ada beberapa bentuk error.

\section{Wilayah Penelitian}

Wilayah untuk penelitian ini dipilih Kanal Banjir Barat. Kanal Banjir Barat terletak di Kota Semarang Kecamatan Semarang Barat dengan panjang sungai $\pm 5 \mathrm{~km}$ dengan lebar dasar sungai berkisar antara $40 \mathrm{~m}$ sampai dengan $150 \mathrm{~m}$.

Kanal Banjir Barat dipilih sebagai lokasi studi karena dasar kemiringan sungai yang cenderung landai dan tidak banyak terdapat kelokan, sehingga diharapkan kestabilan program dapat dicapai.

Tinjauan hidrologi penelitian ini adalah debit dari Sungai Kreo dan Sungai Kripik yang bertemu di Sungai Alang mengalir ke Sungai Garang, debit pada titik pertemuan Sungai Alang dengan Sungai Garang di Tugu Soeharto mengalir ke muara melewati Bendung Simongan dan Kanal Banjir Barat. Pada pemodelan hidraulika, dibuat model sepanjang $\pm 5,55 \mathrm{~km}$.

Batas hulu sebagai input debit rencana adalah potongan melintang dengan nomor 110 yang terletak 550 meter ke arah hulu Bendung Simongan dan batas hilir sebagai input elevasi muka air laut adalah potongan melintang dengan nomor (-8) (muara Kanal Banjir Barat). Jarak potongan melintang sebagai titik pengamatan tinggi muka air, rata - rata berjarak 50 meter. Pengamatan beda elevasi muka air banjir sebagai perbandingan pemodelan aliran satu dimensi steady non-uniform flow dan unsteady non-uniform flow dilakukan pada segmen Kanal Banjir Barat mulai potongan melintang nomor 94 (hilir Bendung Simongan) sampai dengan potongan melintang nomor $(-8)$. 


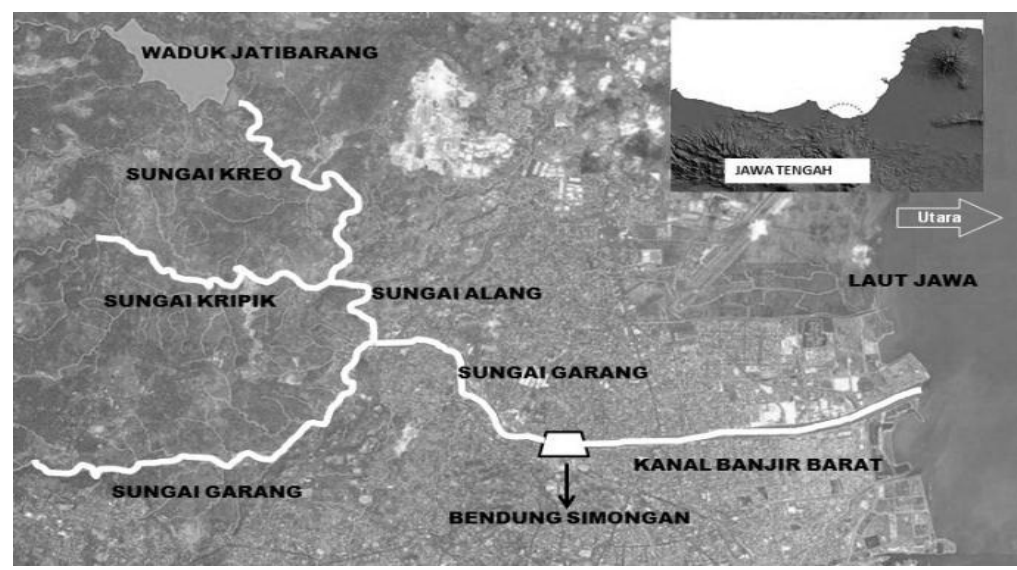

Sumber: Integrated Water Resources and Flood Management Project for Semarang, Detailed Design, 2008

\section{Gambar 1. Denah lokasi Kanal Banjir Barat}

\section{Metode Penelitian}

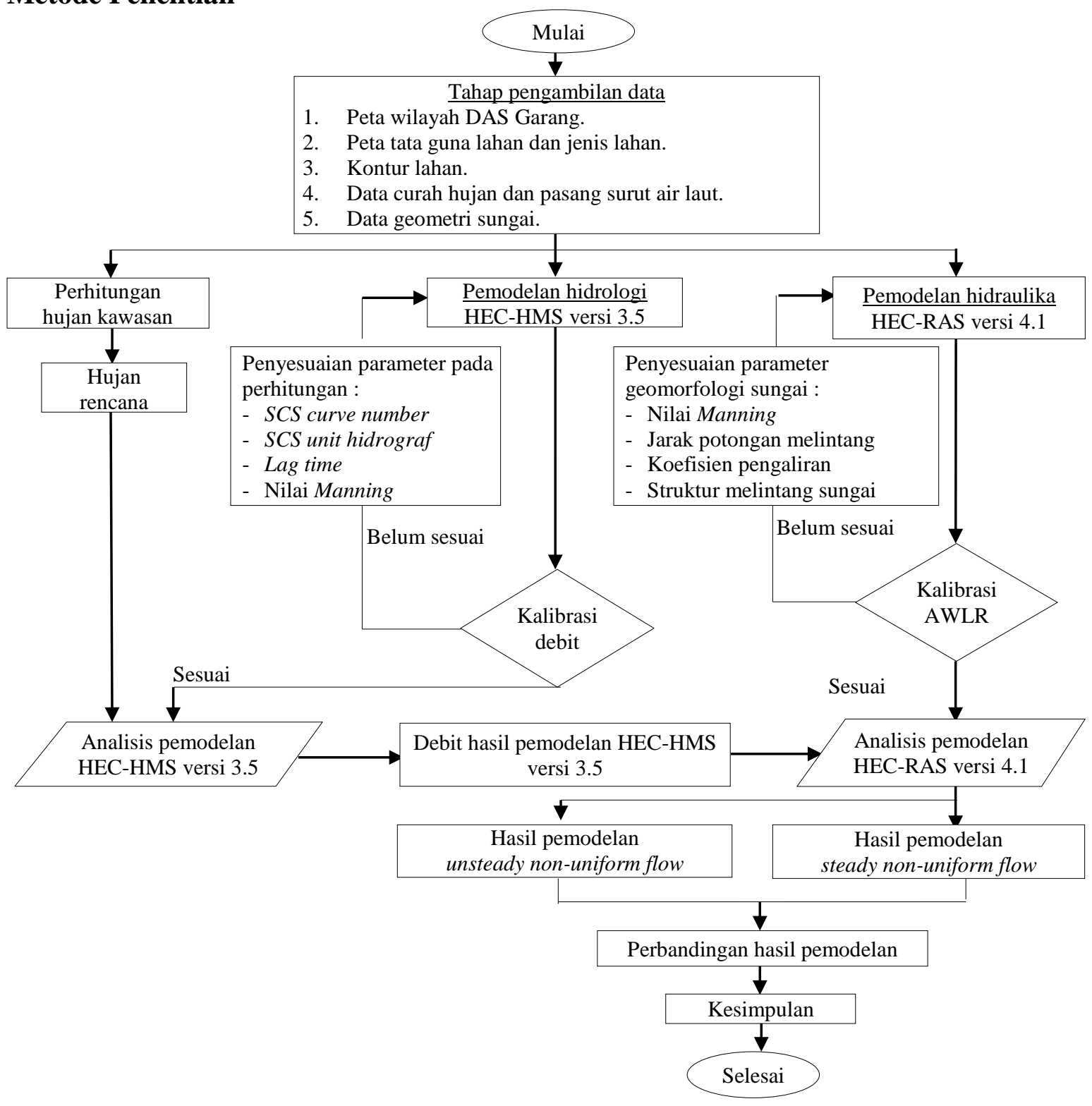

Gambar 2. Bagan alir pelaksanaan penelitian 
Alur pelaksanaan penelitian ditunjukkan pada Gambar 2.

Data pendukung yang diperlukan dalam penelitian ini di peroleh dari paket pekerjaan Analisis Keruntuhan Bendungan Jatibarang pada tahun 2012 oleh PT. Multimera Harapan Engineering Consultant, antara lain: peta wilayah DAS Garang, peta tata guna lahan dan kontur, data geometri sungai, data curah hujan, data pasang surut air laut pada muara Kanal Banjir Barat.

Perhitungan hujan kawasan pada penelitian ini menggunakan metode poligon thiessen. Pada metode poligon thiessen lokasi tiap penangkar hujan yang berdekatan dengan kawasan yang mau dihitung curah hujannya dihubungkan dengan garis lurus. Untuk membentuk poligon thiessen maka ditarik garis tegak lurus pada tengah - tengah tiap garis (Suripin, 2004). Data untuk perhitungan hujan kawasan diambil data hujan selama 20 tahun pada periode tahun 1991 sampai dengan tahun 2010. Pemilihan data hujan tahun 1991 sampai dengan 2010 disesuaikan dengan ketersedian data AWLR yang terdapat pada Bendung Simongan. Selain itu Sungai Garang dan Kanal Banjir Barat pada tahun 2010 sampai dengan 2012 dilakukan kegiatan normalisasi sehingga keakuratan data AWLR tidak dapat dipastikan karena perubahan geomorfologi sungai selama kegiatan normalisasi.

Analisis hidrologi dalam penelitian ini menggunakan program HEC HMS versi 3.5 dengan metode Muskingum Cunge. Metode Muskingum Cunge merupakan metode penelusuran banjir yang menggunakan konsep tampungan. Ada dua bagian tampungan yang akan terjadi akibat masukan (inflow) dan keluaran (outflow) pada sungai yaitu: tampungan prisma dan tampungan baji. Tampungan prisma adalah volume yang digambarkan oleh suatu aliran tunak profil permukaan air, sedangkan tampungan baji adalah tampungan yang terbentuk saat terjadi banjir sehingga terdapat volume tambahan yang mengakibatkan aliran masuk lebih besar dari aliran keluar.

Pemodelan hidraulika aliran satu dimensi steady non-uniform flow dan unsteady non-uniform flow menggunakan HEC-RAS versi 4.1. HEC-RAS dalam menyelesaikan hitungan aliran permanen untuk menghitung profil muka air di sepanjang alur urut dari satu tampang lintang ke tampang lintang berikutnya memakai persamaan energi antara dua tampang lintang. Aliran tak permanen pada HEC-RAS digambarkan dengan persamaan matematis, yang dikenal sebagai persamaan St. Venant. Persamaan St. Venant terdiri dari persamaan kontinuitas (prinsip konservasi massa) dan persamaan momentum (prinsip konservasi momentum) (Istiarto, 2014). Faktor - faktor yang mempengaruhi stabilitas model dan akurasi perhitungan numerik pada pemodelan HEC-RAS unsteady flow, antara lain (HEC-RAS user's manual, 2010):

- Penempatan potongan melintang harus tepat untuk menggambarkan perubahan geometri penampang sungai. Dasar saluran yang curam sangat berpengaruh terhadap penentuan jarak potongan melintang. Dasar saluran curam memerlukan potongan melintang yang lebih banyak, dalam artian jarak yang dibutuhkan lebih berdekatan. Jarak potongan melintang yang terlalu dekat juga tidak lebih baik, karena program akan membaca terdapat perubahan dasar saluran secara tiba - tiba.

- Pemilihan interval waktu komputasi yang tidak terlalu panjang dan tidak terlalu pendek. Bila interval waktu terlalu panjang maka akan terjadi perendaman gelombang banjir sehingga puncak gelombang banjir menjadi lebih rendah. Namun jika waktu terlalu pendek, program menjadi tidak stabil karena perubahan perhitungan waktu seakan - akan terjadi secara tiba - tiba.

- Penurunan dasar saluran yang secara tiba - tiba menyebabkan model melewati kedalaman yang kritis dan mengurangi kestabilan. Peletakan struktur inline (bendung) dengan faktor peredaman yang tepat mampu membuat model lebih stabil.

\section{Analisis dan Pembahasan}

\section{Pemodelan hidrologi}

Sebelum menggunakan model untuk simulasi, model perlu dilkalibrasi. Kalibrasi model menggunakan data pada AWLR (Automatic Water Level Recorder) yang terletak pada Bendung Simongan. Dari hasil kalibrasi pada tanggal 15 Juli 2010 sampai dengan tanggal 22 Juli 2010 debit puncak pada pemodelan HEC-HMS pada tanggal 16 Juli 2010 sebesar 7,00 $\mathrm{m}^{3} /$ detik sedangkan hasil pengukuran AWLR tercatat debit puncak sebesar $6,98 \mathrm{~m}^{3} /$ detik, sehingga terdapat selisih 0,29\% terhadap AWLR. Pada tanggal 19 Juli 2010 debit puncak pada pemodelan HEC-HMS $6,80 \mathrm{~m}^{3} /$ detik dan pencatatan pada AWLR 6,29 $\mathrm{m}^{3} /$ detik, sehingga terdapat selisih $8,11 \%$ terhadap AWLR.

Kalibrasi tanggal 20 Agustus 2010 sampai dengan tanggal 25 Agustus 2010 debit puncak HEC-HMS pada tanggal 22 Agustus 2010 sebesar 10,50 $\mathrm{m}^{3} /$ detik dan hasil pengukuran AWLR tercatat 
debit puncak pada tanggal 22 Agustus 2010 sebesar 9,95 $\mathrm{m}^{3} /$ detik, sehingga terdapat selisih sebesar 5,53\% terhadap AWLR. Pada tanggal 24 Agustus 2010 debit puncak HEC-HMS mencapai $14,90 \mathrm{~m}^{3} /$ detik dan debit pada AWLR tercatat $13,25 \mathrm{~m}^{3} /$ detik, sehingga terdapat selisih $12,45 \%$ terhadap AWLR.

Dari pemodelan HEC-HMS didapat hidrograf debit rencana sebagai input data pemodelan hidraulika menggunakan HEC-RAS. Sebagai input untuk model aliran unsteady non-uniform flow berupa hidrograf debit rencana pada hulu Bendung Simongan.

Data hidrologi untuk model aliran steady nonuniform flow yang digunakan adalah debit maksimum. Model aliran steady non-uniform flow pada HEC-RAS berdasarkan fungsi waktu diasumsikan sebagai aliran permanen, berdasarkan fungsi ruang menjadi aliran berubah beraturan (gradually varied flow) dan saat menemui stuktur hidraulik / stuktur melintang sungai, maka akan menjadi aliran berubah tiba - tiba (rapidly varied flow). Apabila input data aliran hanya terdapat pada hulu sistem sungai, aliran yang terjadi adalah aliran konstan. Sebagai pendekatan aliran steady non-uniform flow terhadap aliran unsteady nonuniform flow pada fungsi ruang, diperlukan data tambahan debit berupa peredaman debit dari hasil hidrologic routing pada beberapa potongan melintang.

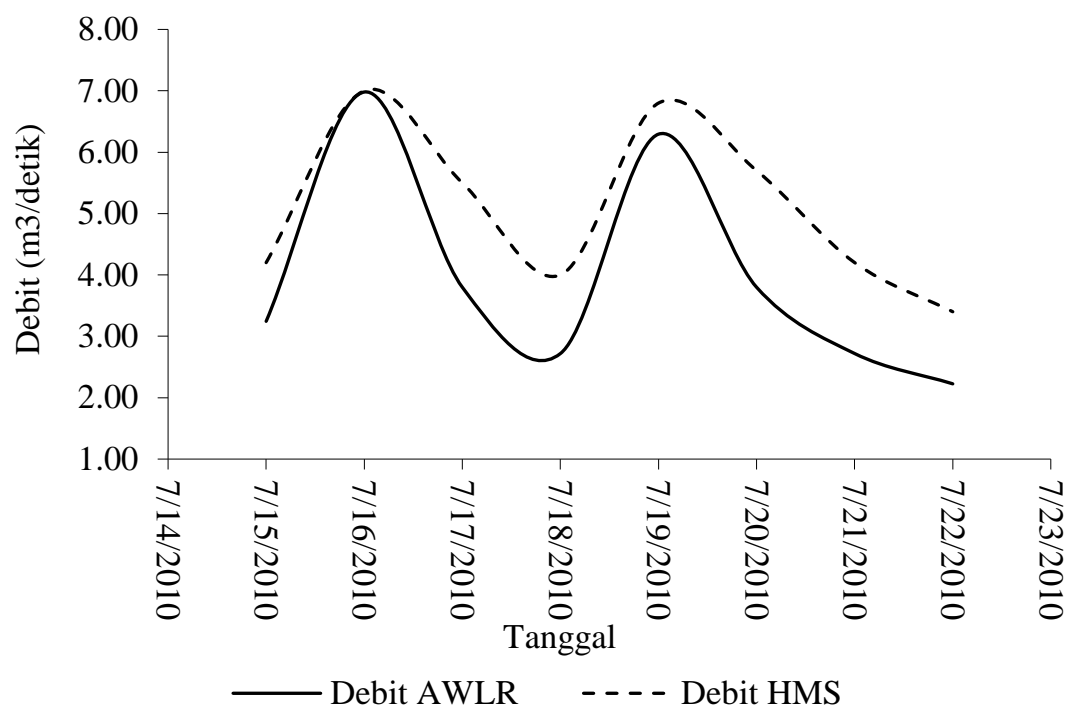

a). Tanggal 15 Juli 2010 - 22 Juli 2010

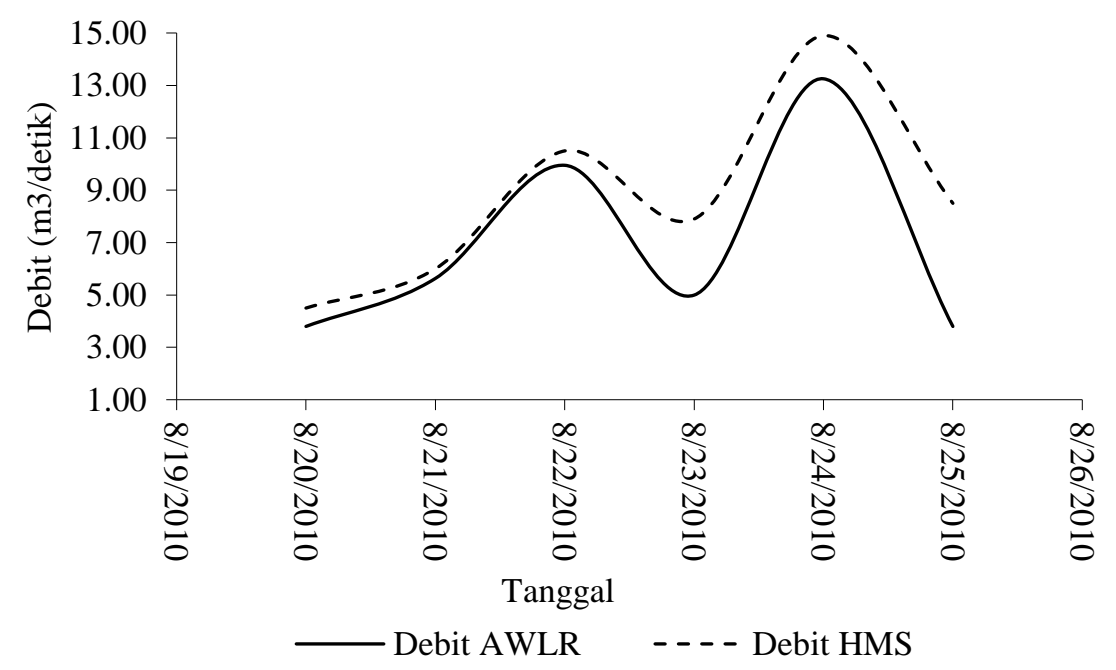

b). Tanggal 20 Agustus 2010 - 25 Agustus 2010

Gambar 3. Kalibrasi pemodelan HEC-HMS 
Pada HEC-HMS, titik-titik pengamatan peredaman debit dilakukan setiap jarak \pm 500 meter, menggunakan model junction.

Junction pada HEC-HMS digambarkan sebagai potongan melintang HEC-RAS. Output junction nomor 110 sebagai masukan boundary conditions pada pemodelan unsteady non-uniform flow berupa data hidrograf debit rencana. Sedangkan untuk pemodelan steady non-uniform flow, output junction nomor 110 yang digunakan sebagai input data aliran adalah debit rencana maksimumnya. Junction berikutnya adalah nomor 94, terletak 200 meter di hilir Bendung Simongan. Kemudian diletakkan beberapa junction ke arah hilir dengan jarak antar junction \pm 500 meter seperti terlihat pada Tabel 1. Peletakan junction hanya sampai pada junction nomor 30. Hal ini dikarenakan kemiringan dasar sungai di hilir junction nomor 30 hingga ke muara kurang dari $0,004 \mathrm{~m} / \mathrm{m}$ dengan elevasi dasar sungai yang relatif sama yaitu elevasi
$-2,5$ meter. Sedang syarat minimal kemiringan dasar sungai menggunakan metode Muskingum Cunge adalah $0,004 \mathrm{~m} / \mathrm{m}$.

\section{Pemodelan hidraulika}

Seperti halnya pemodelan hidrologi, pemodelan hidraulika juga perlu dikalibrasi. Kalibrasi model hidraulika menggunakan data pada AWLR (Automatic Water Level Recorder) yang terletak pada Bendung Simongan dengan metode unsteady non-uniform flow. Hasil kalibrasi pada tanggal 15 Juli 2010 sampai dengan tanggal 22 Juli 2010 elevasi muka air pemodelan HEC-RAS pada tanggal 16 Juli 2010 adalah 0,16 meter, sedangkan hasil pengukuran AWLR tercatat pada elevasi 0,16 meter. Pada tanggal 19 Juli 2010 elevasi muka air pemodelan HEC-RAS adalah 0,15 meter dan pencatatan pada AWLR 0,14 meter, sehingga terdapat selisih $7,14 \%$ terhadap AWLR.

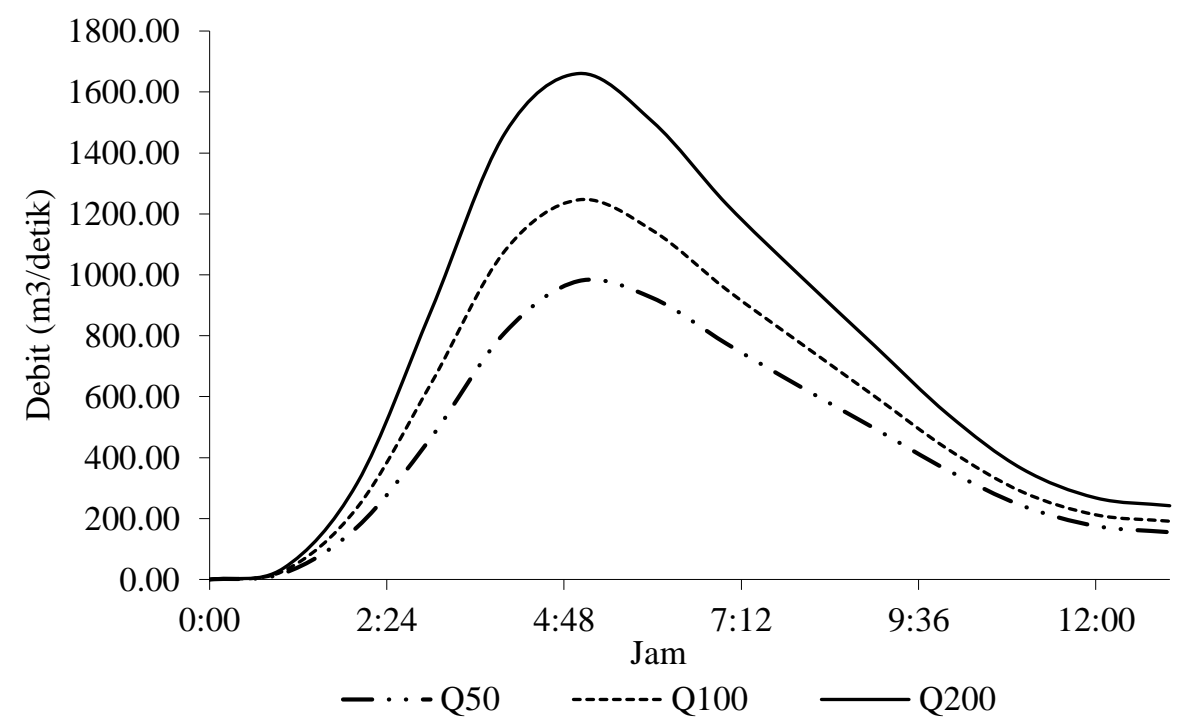

Gambar 4. Hidrograf debit rencana hasil HEC-HMS sebagai boundary conditions hulu pemodelan hidraulika unsteady non-uniform flow

Tabel 1. Hasil HEC-HMS sebagai data aliran pemodelan hidraulika steady non-uniform flow

\begin{tabular}{|c|c|c|c|c|}
\hline \multirow{3}{*}{ No } & \multirow{3}{*}{$\begin{array}{c}\text { Junction } \\
\text { (Potongan } \\
\text { Melintang) }\end{array}$} & \multicolumn{3}{|c|}{ Debit Maksimal } \\
\hline & & \multicolumn{3}{|c|}{$\left(\mathrm{m}^{3} /\right.$ detik $)$} \\
\hline & & $\mathbf{Q}_{50}$ & $\mathbf{Q}_{100}$ & $\mathbf{Q}_{200}$ \\
\hline 1 & 110 & 983,50 & 1246,20 & 1660,60 \\
\hline 2 & 94 & 979,70 & 1241,70 & 1655,00 \\
\hline 3 & 84 & 976,80 & 1238,10 & 1650,40 \\
\hline 4 & 74 & 974,10 & 1234,90 & 1646,50 \\
\hline 5 & 64 & 971,30 & 1231,50 & 1642,40 \\
\hline 6 & 54 & 968,60 & 1228,50 & 1638,10 \\
\hline 7 & 44 & 965,90 & 1225,10 & 1634,10 \\
\hline 8 & 34 & 962,90 & 1221,20 & 1628,80 \\
\hline 9 & 30 & 959,70 & 1217,00 & 1624,20 \\
\hline
\end{tabular}


Hasil kalibrasi tanggal 20 Agustus 2010 sampai dengan tanggal 25 Agustus 2010 elevasi muka air pemodelan HEC-RAS pada tanggal 22 Agustus 2010 adalah 0,21 meter dan hasil pengukuran AWLR tercatat debit puncak pada tanggal 22 Agustus 2010 sebesar 0,20 meter, sehingga terdapat selisih sebesar 5,00\% terhadap AWLR. Pada tanggal 24 Agustus 2010 elevasi muka air pemodelan HEC-RAS mencapai 0,26 meter dan elevasi muka air pada AWLR tercatat 0,23 meter, sehingga terdapat selisih 13,04\% terhadap AWLR.
Sebagai boundary conditions sisi hilir digunakan data pasang surut air laut tertinggi dalam dari tahun 1991 sampai dengan 2010. Data data pasang surut air laut tertinggi terjadi pada tanggal 23 Oktober 2008.

Perbandingan pemodelan unsteady non-uniform flow dan steady non-uniform flow

Perbandingan elevasi muka air banjir hasil pemodelan unsteady non-uniform flow dan steady non-uniform flow dapat dilihat pada Gambar 7.

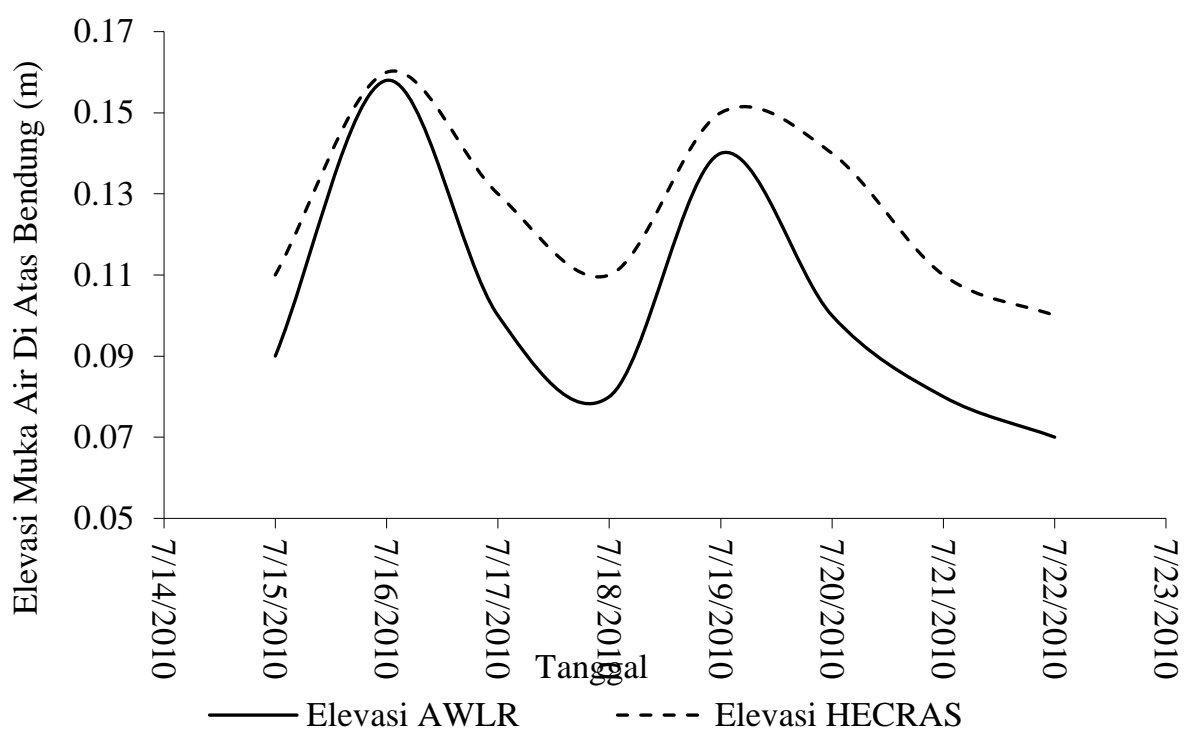

a). Kalibrasi HEC-RAS tanggal 15 Juli 2010 - 22 Juli 2010

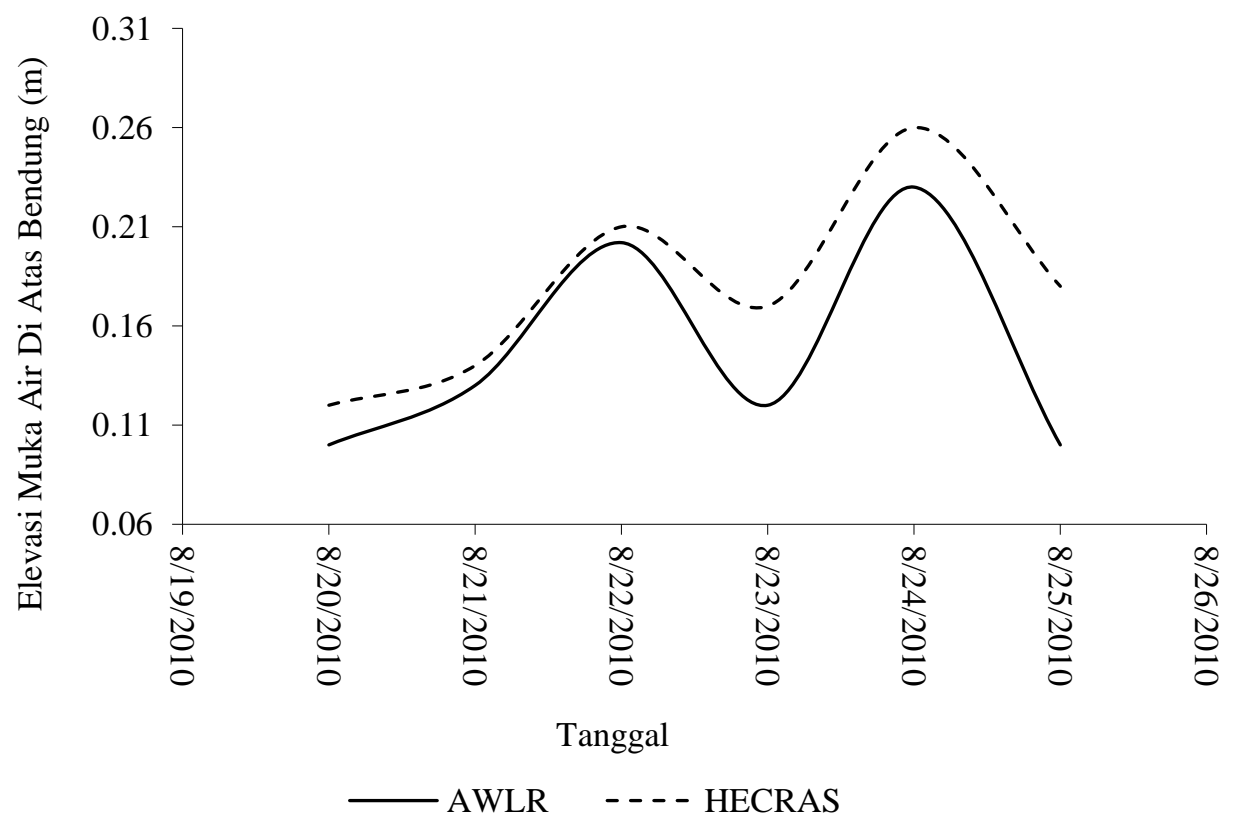

b). Kalibrasi model HEC-RAS tanggal 20 Agustus 2010 - 25 Agustus 2010

Gambar 5. Kalibrasi pemodelan HEC-RAS 


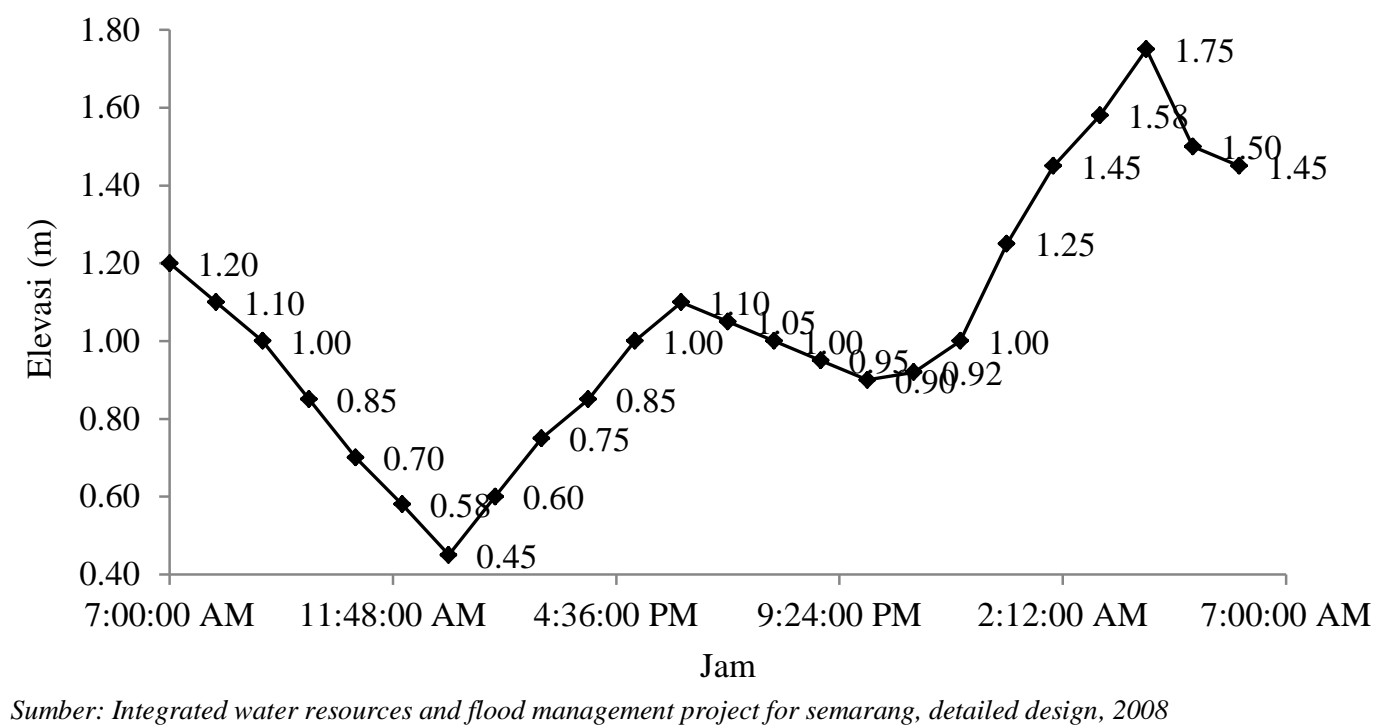

Gambar 6. Data Pasang Surut Air Laut (Elevasi muka air laut tanggal 23 Oktober 2008)

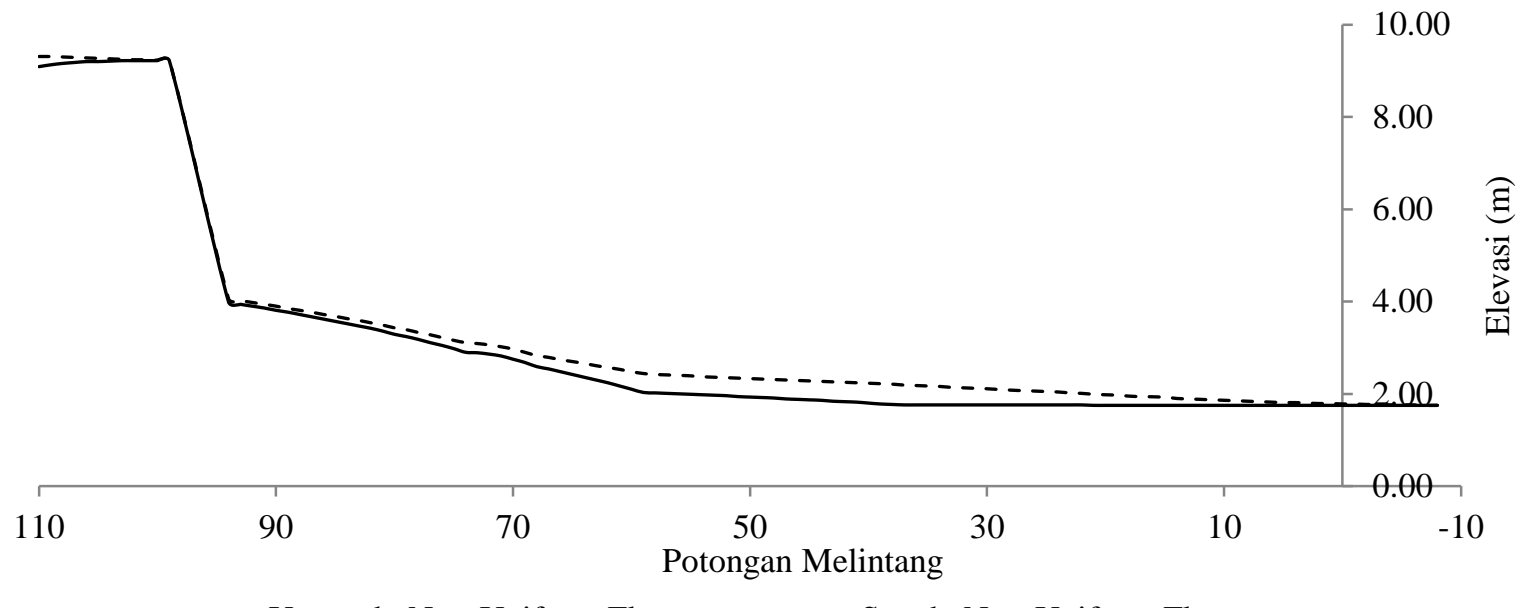

- Unsteady Non-Uniform Flow - - - Steady Non-Uniform Flow

Gambar 7. Perbandingan elevasi muka air hasil pemodelan HEC-RAS unstedy non-uniform flow dengan steady non-uniform flow kala ulang 50 tahun

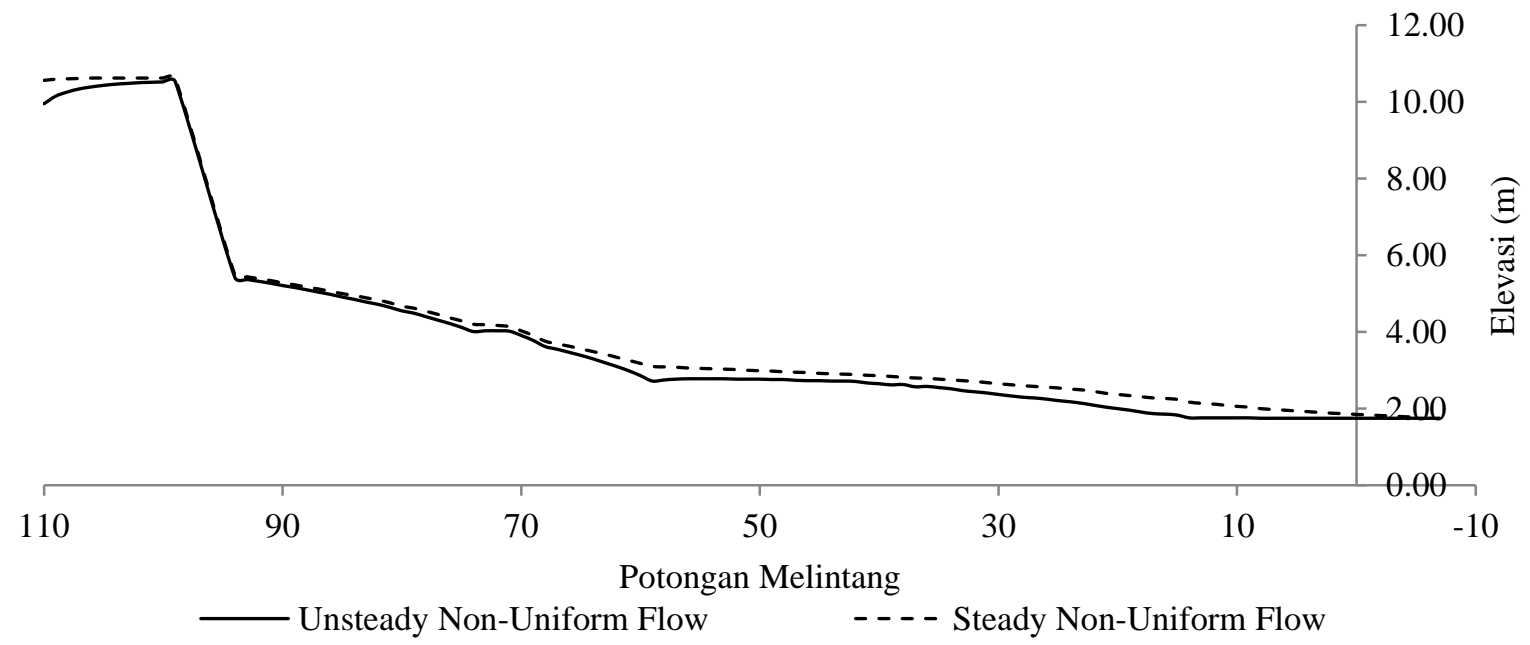

Gambar 8. Perbandingan elevasi muka air hasil pemodelan HEC-RAS unstedy non-uniform flow dengan steady non-uniform flow kala ulang 100 tahun 


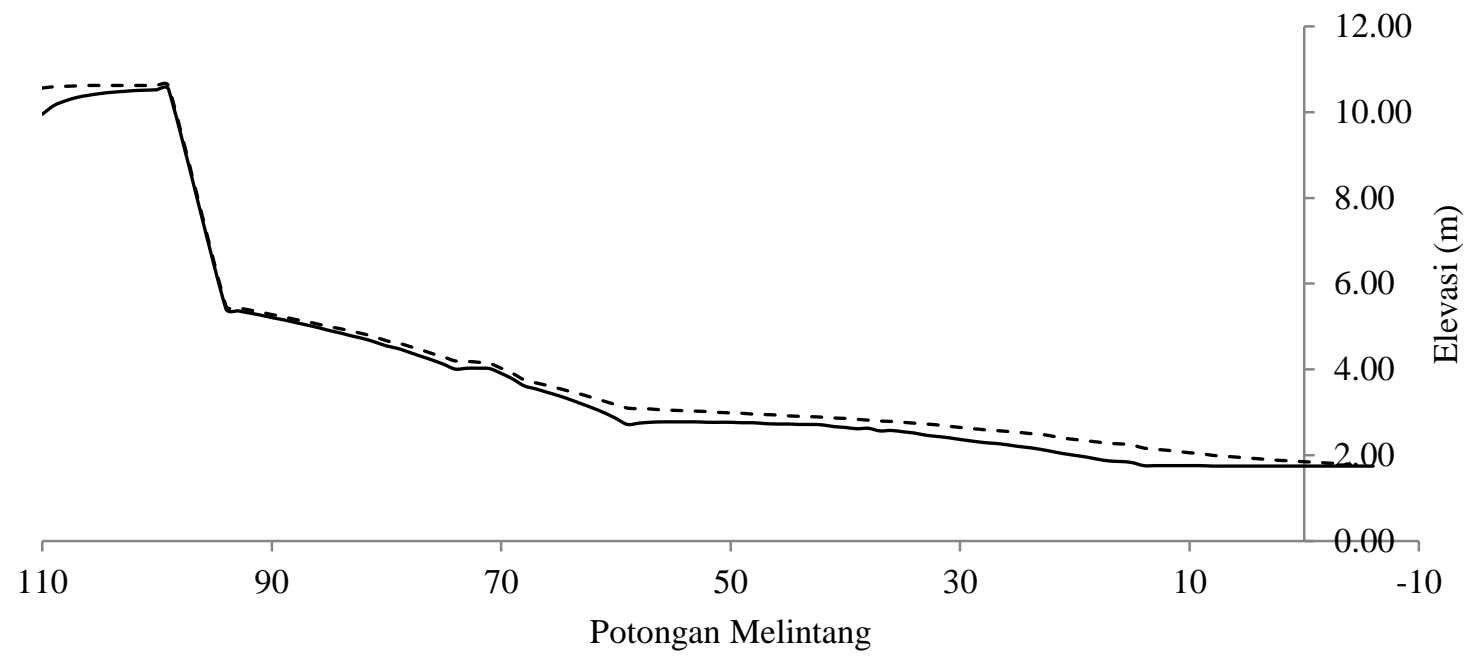

\footnotetext{
_ Unsteady Non-Uniform Flow _ - - - Steady Non-Uniform Flow

\section{Gambar 9. Perbandingan elevasi muka air hasil pemodelan HEC-RAS unstedy non-uniform flow dengan steady non-uniform flow kala ulang 200 tahun}

\section{Pembahasan}

Pemodelan geometri sistem sungai unsteady nonuniform flow dan steady non-uniform flow dapat dijadikan satu model. Pemodelan geometri sungai dilakukan dengan peletakan potongan melintang sungai sebagai bentuk model penampang sungai. Jarak antar penampang melintang pada peneliti ini berjarak \pm 50 meter. Sedangkan input data aliran maupun boundary conditions terdapat perbedaan. Pada pemodelan steady non-uniform flow pada sisi hulu sistem sungai program secara otomatis akan mengarahkan pengguna untuk mengisi data aliran sedangkan boundary conditions berlaku pada setiap potongan melintang di hilir masukan data aliran. Pada pemodelan unsteady non-uniform flow ujung hulu dan hilir sistem sungai, serta masukan aliran tambahan pada potongan melintang yang berlaku adalah boundary conditions.

Waktu analisis untuk analisis unsteady nonuniform flow membutuhkan waktu analisis yang lebih lama daripada steady non-uniform flow. Pada penelitian ini pemodelan unsteady non-uniform flow membutuhkan waktu lima kali lebih lama dari pemodelan steady non-uniform flow.

Pada pemodelan dengan debit debit $\mathrm{Q}_{50}$ dan $\mathrm{Q}_{100}$ report warning terdapat pada 14 potongan melintang, yaitu potongan melintang nomor 8 sampai dengan (-5). Report warning bertambah ketika dilakukan analisis dengan debit $\mathrm{Q}_{200}$ yaitu: potongan melintang nomor 52, 51, 47 sampai dengan 35, 30 dan 8 sampai dengan -5. Hasil dari analisis pemodelan unsteady non-uniform flow dan steady non-uniform flow secara ringkas dapat dilihat pada Tabel 2 .
Pada potongan melintang yang termasuk report warning dilakukan perbaikan model. Perbaikan model yang dilakukan pada penelitian ini meliputi: interpolasi antara dua potongan melintang dan memperpanjang geometri potongan melintang menuju titik kontur yang lebih tinggi dari muka air banjir maksimal. Interpolasi antara dua potongan melintang sebagai upaya mempersempit jarak antara dua potongan melintang dan meminimalkan perubahan bentuk potongan melintang yang ekstrim. Langkah memperpanjang geometri potongan melintang menuju titik kontur yang lebih tinggi dari muka air banjir maksimal, dimaksudkan untuk potongan melintang yang muka air banjir maksimalnya melebihi titik elevasi tertinggi potongan melintang. Dari beberapa percobaan yang dilakukan, beda bentuk antara dua potongan melintang lebih berpengaruh terhadap kestabilan model.

Hasil perbandingan pemodelan unsteady nonuniform flow dan steady non-uniform flow pada potongan melintang yang stabil dengan debit rencana $\mathrm{Q}_{50}, \mathrm{Q}_{100}$, dan $\mathrm{Q}_{200}$, menunjukkan profil muka air banjir maksimal steady non-uniform flow lebih tinggi daripada unsteady non-uniform flow. Pada perbandingan unsteady non-uniform flow dengan steady non-uniform flow didapat selisih elevasi tertinggi 0,44 meter $(24,86 \%)$ pada simulasi debit $\mathrm{Q}_{50}$ dan $\mathrm{Q}_{100}$ dengan jumlah sampel 84, pada simulasi $\mathrm{Q}_{200}$ didapat selisih elevasi tertinggi 0,38 meter $(13,97 \%)$ dengan jumlah sampel 53. Nilai rata - rata selisihnya adalah 0,27 m $(13,16 \%)$ untuk $Q_{50}, 0,25(11,56 \%)$ untuk $Q_{100}$, dan $0,16(4,73 \%)$ untuk $Q_{200}$. 
Andreas Tigor Oktaga, Suripin, Suseno Darsono

Perbandingan Hasil Pemodelan Aliran Satu Dimensi Unsteady Flow dan Steady Flow pada Banjir Kota

Tabel 2. Matrik perbandingan pemodelan aliran satu dimensi unsteady non-uniform flow dan steady non-uniform flow

\begin{tabular}{|c|c|c|c|}
\hline No & Pembanding & $\begin{array}{c}\text { Pemodelan unsteady non- } \\
\text { uniform flow }\end{array}$ & Pemodelan steady non-uniform flow \\
\hline 1. & Metode & $\begin{array}{l}\text { Berupa aliran tak permanen tak } \\
\text { seragam dengan analisis } \\
\text { perhitungan menggunakan } \\
\text { persamaan kekekalan massa } \\
\text { (continuity, conservation of } \\
\text { mass) dan persamaan } \\
\text { momentum. }\end{array}$ & $\begin{array}{l}\text { Berupa aliran berubah beraturan } \\
\text { (gradually varied flow), kecuali di } \\
\text { tempat-tempat struktur hidraulik seperti } \\
\text { jembatan, gorong-gorong, dan bendung; } \\
\text { di tempat-tempat tersebut aliran adalah } \\
\text { rapidly varied flow dan HEC-RAS } \\
\text { memakai persamaan momentum atau } \\
\text { persamaan empiris, bukan persamaan } \\
\text { energi untuk menghitung aliran. }\end{array}$ \\
\hline 2. & $\begin{array}{l}\text { Data yang diperlukan } \\
\text { untuk pemodelan } \\
\text { geometri sungai }\end{array}$ & $\begin{array}{l}\text { Alur dan potongan melintang } \\
\text { sungai. } \\
\text { Perlu pembenahan geometri } \\
\text { sungai bila terdapat report } \\
\text { warning ataupun error. }\end{array}$ & Alur dan potongan melintang sungai. \\
\hline 3. & $\begin{array}{l}\text { Data yang diperlukan } \\
\text { untuk input aliran }\end{array}$ & $\begin{array}{l}\text { Segmen hulu: hidrograf debit } \\
\text { rencana. } \\
\text { Segmen hilir: data pasang surut } \\
\text { air laut }\end{array}$ & $\begin{array}{l}\text { Segmen hulu: debit rencana maksimal } \\
\text { Segmen hilir: data pasang surut air laut } \\
\text { tertinggi } \\
\text { Pada tiap potongan melintang } \\
\text { dibutuhkan data debit sebagai } \\
\text { pendekatan pemodelan unsteady non- } \\
\text { uniform flow }\end{array}$ \\
\hline 4. & $\begin{array}{l}\text { Waktu yang } \\
\text { dibutuhkan HEC-RAS } \\
\text { untuk simulasi } \\
\text { pemodelan }\end{array}$ & $\begin{array}{ll}\mathrm{Q}_{50} & : 5,69 \text { detik } \\
\mathrm{Q}_{100} & : 5,93 \text { detik } \\
\mathrm{Q}_{200} & : 5,68 \text { detik }\end{array}$ & $\begin{array}{ll}\mathrm{Q}_{50} & : 1,11 \text { detik } \\
\mathrm{Q}_{100} & : 1,16 \text { detik } \\
\mathrm{Q}_{200} & : 1,03 \text { detik }\end{array}$ \\
\hline 5. & $\begin{array}{l}\text { Report analisis } \\
\text { pemodelan }\end{array}$ & $\begin{array}{l}\text { 'erlu koreksi jarak antar potongan } \\
\text { melintang nomor } 8 \mathrm{~s} / \mathrm{d}(-5) \\
\text { 'erlu koreksi jarak antar potongan } \\
\text { melintang nomor } 8 \mathrm{~s} / \mathrm{d}(-5) \\
\text { 'erlu koreksi jarak antar potongan } \\
\text { melintang nomor } 52 \mathrm{~s} / \mathrm{d} 51,47 \\
\text { sampai dengan } 35,30 \text { dan } 8 \\
\text { sampai dengan }(-5)\end{array}$ & $\begin{array}{ll}\mathrm{Q}_{50} & : \text { tidak ada } \\
\mathrm{Q}_{100} & : \text { tidak ada } \\
\mathrm{Q}_{200} & : \text { tidak ada }\end{array}$ \\
\hline 6. & $\begin{array}{l}\text { Pengaruh kestabilan } \\
\text { model }\end{array}$ & $\begin{array}{l}\text { Besaran debit } \\
\text { Bentuk penampang / geometri } \\
\text { potongan melintang }\end{array}$ & Tidak ada \\
\hline 7. & $\begin{array}{l}\text { Selisih profil muka air } \\
\text { terhadap pemodelan } \\
\text { unsteady non-uniform } \\
\text { flow pada potongan } \\
\text { melintang yang aliran } \\
\text { airnya stabil }\end{array}$ & & $\begin{array}{l}\text { Pada simulasi } \mathbf{Q}_{\mathbf{5 0}} \\
\text { Maksimal : } 0,44(24,86 \%) \\
\text { Minimal }: 0,07(1,75 \%) \\
\text { Rata - rata }: 0,27(13,19 \%) \\
\text { Pada simulasi } \mathbf{Q}_{\mathbf{1 0 0}} \\
\text { Maksimal : } 0,44(24,86 \%) \\
\text { Minimal : } 0,06(1,31 \%) \\
\text { Rata - rata }: 0,25(11,56 \%) \\
\text { Pada simulasi } \mathbf{Q}_{\mathbf{2 0 0}} \\
\text { Maksimal : } 0,38(13,97 \%) \\
\text { Minimal : } 0,07(1,29 \%) \\
\text { Rata - rata : } 0,16(4,73 \%)\end{array}$ \\
\hline
\end{tabular}




\section{Kesimpulan}

Perbandingan hasil model aliran satu dimensi unsteady non-uniform flow dan steady non-uniform flow menggunakan software HEC-RAS 4.1 dapat disimpulkan sebagai berikut:

1. Pemodelan unsteady non-uniform flow dan steady non-uniform flow menggunakan HECRAS terdiri dari dua komponen utama yaitu geometri sungai dan input aliran.

a. Pembuatan geometri model baik pada pemodelan steady non-uniform flow maupun unsteady non-uniform flow saat pembuatan pemodelan awal tidak terdapat perbedaan.

b. Data aliran pemodelan unsteady nonuniform flow memerlukan data boundary condition sisi hulu berupa hidrograf debit dan sisi hilir berupa pasang surut air laut. Pemodelan steady non-uniform flow memerlukan data aliran pada sisi hulu berupa debit maksimal dan dan sisi hilir berupa elevasi pasang tertinggi. Sebagai pendekatan fungsi waktu steady nonuniform flow terhadap pemodelan unsteady non-uniform flow dibutuhkan tambahan data debit pada beberapa potongan melintang. Pada penelitian ini diambil tiap jarak \pm 500 meter.

2. Kalibrasi model dibutuhkan untuk penyesuaian nilai parameter - parameter model supaya hasil yang didapat mendekati keadaan nyata. Hasil kalibrasi yang digunakan adalah pada puncak hidrograf, karena data yang digunakan adalah data harian. Namun pola hidrograf kalibrasi sudah mendekati hasil pengukuran AWLR, sehingga parameter hasil kalibrasi dapat digunakan.

3. Dari segi proses waktu simulasi pemodelan, waktu yang diperlukan untuk proses analisis pemodelan steady non-uniform flow lebih cepat dibanding proses analisis pemodelan unsteady non-uniform flow. Kisaran waktu yang dibutuhkan untuk analisis pemodelan unsteady non-uniform flow adalah 5,69 detik sampai 6,93 detik, sedangkan waktu yang digunakan untuk analisis pemodelan steady non-uniform flow 1,01 detik sampai dengan 1,16 detik. Sehingga beda waktu yang diperlukan untuk analisis pemodelan steady non-uniform flow sekitar lima kali lebih cepat dibanding analisis pemodelan unsteady non-uniform flow.

4. Pada pemodelan unsteady non-uniform flow perubahan bentuk penampang melintang sungai mempengaruhi ketidakstabilan model. Sedangkan untuk pemodelan steady nonuniform flow tidak terdapat report warning, yang mengindikasikan analisis model berjalan stabil.

5. Pemodelan steady non-uniform flow memiliki kecenderungan elevasi muka air lebih tinggi dari hasil pemodelan unsteady non-uniform flow. Selisih rata - rata elevasi muka air banjir kurang dari $15 \%$ ( $\pm 0,3$ meter). Nilai rata - rata selisihnya adalah 0,27 meter $(13,16 \%)$ untuk $\mathrm{Q}_{50}, 0,25$ meter $(11,56 \%)$ untuk $\mathrm{Q}_{100}$, dan 0,16 meter $(4,73 \%)$ untuk $\mathrm{Q}_{200}$. Sehingga pemodelan steady non-uniform flow dengan penambahan data aliran hasil peredaman debit dari hasil hidrologic routing dapat digunakan sebagai versi pendamping pemodelan unsteady nonuniform flow.

\section{Saran}

1. Dalam memodelkan geometri sungai, sebaiknya ujung batas kanan dan kiri tiap potongan melintang merupakan daerah dengan elevasi lebih tinggi dari muka air banjir rencana.

2. Penambahan sampel dan referensi akan memberikan gambaran yang lebih detail mengenai prosentase keakuratan hasil pemodelan steady non-uniform flow sebagai versi pendamping untuk hasil pemodelan unsteady non-uniform flow.

3. Perlu dilakukan kajian yang lebih mendalam mengenai pengaruh besaran debit terhadap jarak potongan melintang dan interval waktu tiba debit.

\section{Daftar Pustaka}

Balai Besar Wilayah Sungai Pemali-Juana, 2008. Integrated and Water Resources and Flood Management Project for Semarang, Detailed Design, Semarang.

Goodell, C., 2010. Steady versus Unsteady Flow, Diakses Mei 2015, dari http://hecrasmodel.blogspot.com/2010/01/steadyversus-unsteady-flow.html.

Chow, Ven Te, 1992. Hidrolika Saluran Terbuka (Open Channel Hydraulics), Erlangga, Jakarta.

Istiarto, 2014. HEC-RAS: Steady atau Unsteady Flow Analysis. Diakses Mei 2015, dari http://istiarto.staff. 
ugm.ac.id/index.php/2014/01/hec-ras-steady-atau unsteady-flow-analysis/\# comment-2189.

Istiarto, 2014. Simulasi Aliran 1-Dimensi Dengan Bantuan Paket Program Hidrodinamik HEC-RAS. Diakses dari http://istiarto.staff.ugm.ac.id/

PT. Multimera Harapan Engineering Consultant, 2012. Analisis Keruntuhan Bendungan Jatibarang, Semarang.
Suripin, 2004. Sistem Drainase Perkotaan yang Berkelanjutan, Andi, Yogyakarta.

US Army Corps of Engineers Hidrologic Engineering Center, 2010. Technical Reference Manual HEC-HMS, USA.

US Army Corps of Engineers Hidraulogic Engineering Center, 2010. User's Manual HECRAS, USA. 